\title{
Regulatory reform and productivity change in Indian banking
}

Article

Published Version

Casu, B., Ferrari, A. and Zhao, T. (2013) Regulatory reform and productivity change in Indian banking. Review of Economics and Statistics, 95 (3). pp. 1066-1077. ISSN 15309142 doi: https://doi.org/10.1162/REST_a_00298 Available at https://centaur.reading.ac.uk/28822/

It is advisable to refer to the publisher's version if you intend to cite from the work. See Guidance on citing.

To link to this article DOI: http://dx.doi.org/10.1162/REST_a_00298

Publisher: MIT Press

All outputs in CentAUR are protected by Intellectual Property Rights law, including copyright law. Copyright and IPR is retained by the creators or other copyright holders. Terms and conditions for use of this material are defined in the End User Agreement.

\section{www.reading.ac.uk/centaur}

\section{CentAUR}

Central Archive at the University of Reading

Reading's research outputs online 


\title{
REGULATORY REFORM AND PRODUCTIVITY CHANGE IN INDIAN BANKING
}

\author{
Barbara Casu $^{\mathrm{a}}$, Alessandra Ferrari ${ }^{\mathrm{b} *}$, Tianshu Zhao $^{\mathrm{c}}$
}

Abstract - This paper examines the impact of regulatory reform on productivity growth and its components for Indian banks in 1992-2009. We estimate parametric and non-parametric efficiency frontiers, followed by Divisia and Malmquist indexes of Total Factor Productivity respectively. To account for technology heterogeneity among ownership types we utilise a metafrontier approach. Results are consistent across methodologies and show sustained productivity growth, driven mainly by technological progress. Furthermore, results indicate that different ownership types react differently to changes in the operating environment. The position of foreign banks becomes increasingly dominant and their production technology becomes the best practice in the industry.

Key words: Deregulation; Productivity Change; Ownership; DEA; SFA, Metafrontier. JEL Classification: G21; G28; G32; D24; C16; C23

a Cass Business School, City University, London, UK; ${ }^{b}$ Department of Economics, University of Reading, UK; ${ }^{c}$ Department of Economics, Stirling University, UK.

We would like to thank two anonymous referees for very useful comments and suggestions which significantly improved this paper. Usual disclaimers apply. 


\section{Introduction}

The past two decades have witnessed deregulatory policy reforms in banking industries around the world. These reforms have aimed to increase competition in order to promote productive financial systems, which would ultimately foster the development of the real economy. Deregulation is usually expected to stimulate productivity growth via the general advancement of production technology and the efficiency improvements of individual banks. ${ }^{1}$ Re-regulation, on the other hand, is often expected to work as a constraint on the activity of banks with the aim of long term stability. Empirical evidence to support these aforementioned assertions is mixed, with some studies reporting improvements in productivity following financial reforms, while others suggest little, no, or even negative productivity growth. ${ }^{2}$ Differences in empirical findings are likely to arise from: differences in the applied modelling techniques utilised; difficulties in disentangling the sources of productivity growth (arising from technological progress, scale or efficiency improvements); and complex relationships between ownership structure and efficiency and productivity changes. ${ }^{3}$

It is against this background that we seek to extend previous research by presenting an assessment of the effects of regulatory reforms on productivity growth, its sources, and on the relationship between bank performance and ownership types for Indian banks over the period 1992 to 2009 . The Indian case is particularly suited to our research questions since it is a representative illustration of a gradualist approach to reform a banking system that was characterised by financial repression. The reforms started in 1992 and were guided by two Narasimham Committee reports, in 1991 and 1998 respectively. The period 1992-1997 saw the introduction of policy instruments aimed at promoting competition (deregulation), whereas from 1998 onwards the policy focus shifted towards the long run stability of the banking system (prudential re-regulation). ${ }^{4}$ The whole reform process can thus be divided, at 
least in theory, in two stages with the year 1997 as the watershed. Moreover, the Indian Government introduced a uniform regulatory framework to the different ownership types, which gives us an opportunity to investigate the impact of regulatory reform on the ownership-performance relationship in a market with a level playing field. ${ }^{5}$

Methodologically, we utilise two complementary approaches: a non-parametric metafrontier sequential Malmquist TFP index and a parametric metafrontier Divisia index. To our knowledge, this is the first study to perform an analysis of productivity change and its components within a metafrontier framework, both in a parametric and non-parametric setting. To test whether different approaches lead to similar policy conclusions, both share a common framework in terms of dataset, variables definition and behavioural assumptions. Having estimated technology gaps between ownership specific frontiers and metafrontier, a natural extension is to analyse them more closely and then test for convergence, that is the attainment of productivity equality in the long run. We do this by using the augmented Dickey-Fuller (ADF) test.

To anticipate our main results, we find that the reforms have fostered sustained TFP growth, driven mainly by technological progress. Results also indicate that state-owned, private and foreign banks reacted differently to changes in the operating environment. Specifically, regulatory changes generated a very favourable environment for foreign banks, which enabled them to use the best available technology in the industry and engage in cost technology innovation. On the other hand, the increasing technological gap between the best practice and the private and state banks frontiers indicates a lack of significant technological spillovers between different types of bank.

The remainder of the paper is structured as follows: Section 2 provides a review of the relevant literature. Section 3 describes the data set and the variables used in the construction 
of the estimable models, while Section 4 presents a detailed exposition of the methodology utilised. Section 5 discusses the empirical findings and finally Section 6 concludes.

\section{Literature review}

There is a vast literature investigating bank efficiency, its components and its determinants using both parametric and non parametric approaches. ${ }^{6}$ Most studies have measured technical and cost efficiency and, to a lesser extent, revenue and profit efficiency and productivity change. While early studies investigate mainly the US and EU banking markets, in recent years the number of studies focusing on developing countries has increased, mainly due to the unprecedented economic reforms implemented in those countries. Indian banking is no exception and starting from the mid-1990s the outcomes of the Indian reform process have been extensively analysed. Bhattacharyya et al. (1997) investigated the productivity growth of Indian public sector banks in the pre-reform period (1970 - 1992) and found that nationalisation curtailed bank productivity growth. Kumbahakar and Sarkar (2003)'s sample included both public sector and private banks in the period 1985-1996 and found that reforms did not deliver the expected TFP growth. The empirical literature on developing nations generally finds relatively low efficiency of state-owned institutions. In India, though, a number of studies, using competing methodologies and different time periods, seem to provide convincing evidence of higher average cost (and profit) efficiency of public sector banks (Sathye, 2003; Bhaumik and Dimova, 2004; Sensarma, 2006; Das and Ghos, 2006; 2009; Zhao et al., 2010; Ray and Das, 2010, among others). Das and Ghosh (2006) posit that public banks might be more efficient as government ownership may have facilitated recapitalisation at the onset of reforms. The literature seems also to agree on the poor performance of smaller private banks and on the considerable differences among banks both in terms of efficiency and productivity change. 
The fact that the three ownership types co-exist and, to a certain extent, compete on the Indian banking market does not imply that they form a homogenous group. State, private and foreign ownership entail different organisational forms and incentive structures, which are likely to result in different operational behaviour. At the macro level, Bhaumik et al. (2011) find evidence that different ownership types react differently to monetary policy initiatives of the Reserve Bank of India. These varying reactions might be driven by differences in the structure of their balance sheet, particularly in terms of asset composition (Stein, 1998). Theory suggests a number of reasons as to why different types of banks lend to different types of firms, mostly based on information asymmetries. For example, Stein (2002) suggests that foreign banks may be less able to process "soft" information about local firms and therefore may prefer to lend to more "transparent" larger firms. Foreign banks might also have a comparative advantage in granting large loans. In contrast, state-owned banks often have to lend to "priority sectors" such as small and medium size enterprises, state-owned firms and firms in rural areas. Based on Indian data, Berger et al. (2008) find evidence of these different lending relationships.

These significant differences are often overlooked by the existing bank efficiency literature; however the importance of properly accounting for heterogeneity has been highlighted in a handful of recent studies (Bos and Schmiedel, 2007; Kontolaimou and Tsekouras, 2010). The assumption underlying the estimation of efficiency against a common frontier is that all banks in the industry are homogenous and utilise the same technology. If this assumption is not correct it will result in biased estimators and efficiency measures. Koetter and Poghosyan (2009) identify two main types of systematic differences across and within national banking markets: the first type of heterogeneity pertains to the environment in which banks operate and is exogenous to managers, although it affects their choice of available technology. The second type pertains to managerial choices and therefore affects efficiency, that is the ability 
to attain the optimum benchmark rather than the shape of the efficient frontier. Our study builds upon this recent strand of literature by employing the metafrontier approach (Battese $e t$ al., 2004; O'Donnell et al., 2008) to account for the possibility of technological differences among ownership types.

\section{Data and variables definition}

\section{A. Data}

The data were collected from the Reserve Bank of India and cover all commercial banks (foreign, domestic private and state owned) operating in India from 1992 until 2009.

With the guide of homogeneity criteria and in line with previous literature, we excluded regional rural banks and foreign banks that consistently had less than two branches over the entire sample period. In both cases, their lines of business are very different from the nationwide operations of other commercial banks. The resulting sample is an unbalanced panel data set of a total of 1230 observations. Table 1 gives a snapshot of the relative weight of the three ownership categories and of how the sample relates to the total market (proportion of total assets). All data were deflated using the GDP deflator using 1994 as base year.

\section{< Insert Table 1>}

\section{B. Variable definition}

To identify the inputs and outputs variables we follow the intermediation approach (Sealey and Lindley, 1977) and employ a two-input, three-output specification. The three chosen outputs are performing loans $\left(\mathrm{y}_{1}\right)$, other earning assets $\left(\mathrm{y}_{2}\right)$ and fee-based income $\left(\mathrm{y}_{3}\right) .{ }^{7}$ The revenues with respect to these three outputs are given by interest income on loans, interest income on total other earning assets and non-interest income respectively. ${ }^{8}$ The two chosen 
inputs are total loanable funds (the sum of deposits and money market funding) and noninterest operating cost (which includes both the cost of the labour input and of physical capital). The price for total loanable funds $\left(\mathrm{w}_{1}\right)$ is calculated as the ratio of total interest expenditure to total loanable funds, and the price for non-interest operating cost $\left(\mathrm{w}_{2}\right)$ is given by the ratio between non-interest operating cost and total assets. The number of branches is also introduced separately to proxy for size. Summary statistics for outputs and inputs are given in Table 2.

To account for the macroeconomic environment and prevent bias especially in the estimation of technical change we also include the cash reserve ratio (CRR), the statutory liquidity ratio (SLR) and a measure of the reliance of the economy upon the banking sector as opposed to other sources of finance (Mac). Finally in the econometric specification we also specify a dummy variable $\mathrm{R}$ to capture the period before and after re-regulation (before and after 1997).

\section{<Insert Table 2>}

\section{Methodology}

\section{A. Empirical framework}

The measurement of total factor productivity change (TFP) and its components can be performed via the estimation of efficiency frontiers, either using Stochastic Frontier Analysis (SFA) or Data Envelopment Analysis (DEA), which lead respectively to the calculation of a Divisia index and of a Malmquist index of TFP change (Malmquist, 1953). ${ }^{9}$ In this paper we make a number of methodological contributions to the literature: firstly, we use both parametric and non-parametric techniques as they have well known complementary properties and consistency in their results strengthens the analysis and is particularly useful for regulators and other decision makers (Bauer et al., 1998; Casu et al., 2004). To improve comparability, we implement a sequential DEA approach (Tulken and Vanden Eeckaut, 
1995) which leads to the estimation of a sequential Malmquist TFP index. In addition, unlike most of the literature, for the decomposition of the Malmquist index we do not follow Färe et al. (1994), since their method, albeit very popular, is actually valid only under the assumption of constant returns to scale. We follow instead the method proposed by Ray and Desli (1997), which is valid under variable returns to scale and allows the proper separation of scale effects from the rest. Finally, we recognise the heterogeneous nature of our data across ownership types, and therefore we address this issue in the context of a metafrontier framework (Battese et al, 2004; O'Donnell et al, 2008). We then estimate both a non-parametric sequential metafrontier Malmquist TFP index and a parametric metafrontier Divisia index to assess productivity change.

\section{B. Group-specific frontiers: SFA, DEA and Divisia and Malmquist indexes}

In an input minimization perspective, an efficiency frontier is defined as the minimum level of input(s) for a given level of output(s), and the efficiency of a firm can be measured by means of a "distance function" $D$ (Shephard 1953, 1970): this is a radial measure of the distance of that firm from the frontier such that $\mathrm{D}=1$ when the firm is fully efficient and $\mathrm{D}>1$ otherwise.

Data Envelopment Analysis constructs a piece-wise linear convex frontier from the linear combination of the best practices among the observations (Charnes et al., 1978, 1981). In the case of $i=1 \ldots N$ firms that produce $m=1, \ldots, M$ outputs using $j=1 \ldots, J$ inputs at time $t$ and with variable returns to scale, the efficiency of each firm is calculated by solving the following linear programming problem (once for each firm). 


$$
\begin{gathered}
\left\{D^{t}{ }_{o}\left(x_{i t}, y_{i t}\right)\right\}^{-1}=\min _{\theta, \lambda} \theta_{o} \\
\text { s.t. } \quad \sum_{i=1}^{N} y_{i m}^{t} \lambda^{t}{ }_{i} \geq y_{o m}^{t} \\
\quad \sum_{i=1}^{N} x_{i j}^{t} \lambda^{t}{ }_{i} \leq \theta_{o} x_{o j}^{t} \\
\lambda^{t}{ }_{i} \geq 0, \sum_{i}^{N} \lambda_{i}^{t}=1
\end{gathered}
$$

Where $\theta_{o}=1 / D_{o}^{t}$ so that $\theta_{o} \leq 1$.

For the calculation of TFP we follow Ray and Desli (1997) and we define the Malmquist index for the $k$-th ownership between any two times $t$ and $t+1$ and with variable returns to scale as:

$$
\begin{gathered}
M^{k}\left(X_{t+1}, Y_{t+1}, X_{t}, Y_{t}\right)=\left[\frac{D_{v, t}^{k}\left(X_{t}, Y_{t}\right)}{D_{v, t+1}^{k}\left(X_{t+1}, Y_{t+1}\right)}\right] *\left[\frac{D_{v, t+1}^{k}\left(X_{t}, Y_{t}\right)}{D_{v, t}^{k}\left(X_{t}, Y_{t}\right)} \frac{D_{v, t+1}^{k}\left(X_{t+1}, Y_{t+1}\right)}{D_{v, t}^{k}\left(X_{t+1}, Y_{t+1}\right)}\right]^{1 / 2} * \\
*\left[\frac{D_{c, t+1}^{k}\left(X_{t}, Y_{t}\right)}{D_{v, t+1}^{k}\left(X_{t}, Y_{t}\right)} \frac{D_{v, t+1}^{k}\left(X_{t+1}, Y_{t+1}\right)}{D_{c, t+1}^{k}\left(X_{t+1}, Y_{t+1}\right)} \frac{D_{c, t}^{k}\left(X_{t}, Y_{t}\right)}{D_{v, t}^{k}\left(X_{t}, Y_{t}\right)} \frac{D_{v, t}^{k}\left(X_{t+1}, Y_{t+1}\right)}{D_{c, t}^{k}\left(X_{t+1}, Y_{t+1}\right)}\right]^{1 / 2} \\
=E C^{k} * T C^{k} * S C^{k}
\end{gathered}
$$

From (2) we can see that the Malmquist index is calculated as the ratio of distance functions and it is given by the product of three components: the change in efficiency (EC), technological change (TC), and scale change (SC). ${ }^{10}$ For each of these components, a score larger/smaller than unity indicates an improvement/worsening of the corresponding measure and a score equal to 1 indicates no change. The same is true for the overall TFP measure resulting from the multiplication of the three scores.

Equation (1) is usually estimated separately for each time period, and the resulting Malmquist index therefore compares year pairs every time independently; this often translates into wide oscillations, as shifts of the frontier induced by random shocks are confused with changes in 
technology. We avoid this problem by estimating (1) and (2) sequentially (Tulken and Vanden Eeckaut, 1995). This means that the estimation of (1) (and therefore subsequently of (2)) is conducted each time including not only the current year but also all the years preceding it, which is equivalent to assuming that technological knowledge accumulates over time. ${ }^{11}$ The sequential estimation has also the additional advantage of reducing the well known dimensionality problem of $\mathrm{DEA}^{12}$, and it also enhances the comparability with SFA that uses time trends to model technological change (O' Donnell et al, 2008).

The stochastic frontier model is an econometric method that consists of a (cost or production or profit) function with a composite error term, made up of two separate, although jointly estimated, components: stochastic noise and inefficiency (Aigner et al., 1977; Meeusen and Van den Broek, 1977). In this paper we estimate a stochastic translog cost frontier with non constant inefficiency whose mean depends upon a set of covariates (Battese and Coelli $1995)^{13}$. We choose a translog functional form so our model is

$$
\begin{aligned}
& \ln C_{i t}=\beta_{0}+\sum_{m=1}^{M} \alpha_{m} \ln y_{m i t}+\sum_{j=1}^{J} \beta_{j} \ln w_{j i t}+\sum_{m=1}^{M} \sum_{q=1}^{M} \alpha_{m q} \ln y_{m i t} \ln y_{q i t}+ \\
& +\sum_{n=1}^{J} \sum_{j=1}^{J} \beta_{n j} \ln w_{n i t} \ln w_{j i t}+\sum_{j=1}^{J} \sum_{m=1}^{M} \gamma_{j m} \ln w_{j i t} \ln y_{m i t}+ \\
& +\lambda_{1} T+\lambda_{2} T^{2}+\sum_{m=1}^{M} \theta_{m} T \ln y_{m i t}+\sum_{j=1}^{J} \zeta_{j} T \ln w_{j i t}+ \\
& +a_{r} R+a_{r t} R T+\sum_{m=1}^{M} \ell_{m} R \ln y_{m i t}+\sum_{j=1}^{J} \rho_{j} R \ln w_{j i t}+\sum_{p}^{P} \eta_{p} E_{p i t}+v_{i t}+u_{i t}
\end{aligned}
$$

Where $\mathrm{v}_{\mathrm{it}} \sim \mathrm{N}\left(0, \sigma^{2}\right)$ is noise and $u_{i t} \sim \mathrm{N}^{+}\left(\delta \mathrm{Z}_{\mathrm{it}}, \sigma_{u}^{2}\right)$ is inefficiency, modelled as

$$
u_{i t}=\delta_{0}+\delta_{1} T+\delta_{2} T T+\delta_{3} R+\varepsilon_{i t}
$$

With $\varepsilon_{\text {it }} \sim \mathrm{N}\left(0, \sigma_{\varepsilon}^{2}\right)$ truncated at the variable point $-\delta^{\prime} Z_{i t}$ to allow for the non-negativity constraint on $\mathrm{u}_{\mathrm{it}}$, so that $\varepsilon_{\mathrm{it}} \geq-\delta^{\prime} Z_{i t}$. 
In (3) $C_{i t}$ is the observed total operating cost of bank $i$ at time $t$, and it depends on inputs prices $w$ and outputs $y . R$ is a dummy variable set equal to 1 for the period following reregulation (1998-2009) and $T$ is time; together with their interaction with inputs and outputs they model (neutral and non neutral) technical change and changes in technology following re-regulation. The exogenous environmental variables that we described in the data section are in the vector $E$.

Equation (4) models inefficiency as a function of time and re-regulation, as the relevance of the difference between ownerships is already captured by the estimation of separate frontiers ${ }^{14}$. Equations (3) and (4) are estimated simultaneously by Maximum Likelihood. Following the procedure outlined in Kumbhakar and Lovell (2003) we define and calculate the Divisia index of TFP change for each of the $k$ ownerships as

$$
\begin{aligned}
& \stackrel{\bullet}{T F P^{k}}=[1-\varepsilon(Y, W, R, T, E ; \beta)] \dot{Y^{c}}-\dot{C}(Y, W, R, T, E ; \beta)-\frac{\partial \ln C}{\partial E}+ \\
& +\sum_{j=1}^{J}\left[S_{j}-S_{j}(Y, W, R, T, E ; \beta)\right] \dot{w j}-\frac{\partial U}{\partial t}+\left(\dot{Y}-\dot{Y^{c}}\right)
\end{aligned}
$$

The index therefore is computed as the sum of six components, a positive net value in each of which translates into a positive growth in TFP, to be interpreted as follows. The first component measures the scale effect $\left(\mathrm{SC}^{\mathrm{k}}\right)$. The second component represents technological progress, measured as shifts of the frontier due to the passing of time $\left(\mathrm{TC}^{\mathrm{k}}\right)$. The third component measures the impact on TFP of all the environmental variables in (3) $\left(\mathrm{EX}^{\mathrm{k}}\right)$. The fourth term is a measure of allocative inefficiency, specified as a deviation of the observed inputs cost shares from their optimal ones $\left(A L L C{ }^{k}\right)$. The fifth component measures the change in cost efficiency $\left(\mathrm{EC}^{\mathrm{k}}\right)$ and finally the last is the so-called mark-up effect $\left(\mathrm{MU}^{\mathrm{k}}\right)$, representing departures from marginal cost pricing and/or from an equi-proportionate markup for every output (Denny et al., 1981; Kumbhakar and Lozano-Vivas, 2005). 
To compute equation (5) for the ownership specific cases we use the parameters estimates of equations (3) and (4).

\section{The estimation of metafrontiers}

When firms in different groups (countries, industry, ownership types etc.) face different technologies their (production or cost functions and) frontiers have to be estimated separately, precluding the possibility of comparisons among them. More formally, if there are $k$ different technology sets in an input perspective at every time $t$ there will be $k$ different input sets each defined as

$$
L_{t}^{k}=\left\{X_{t}^{k}:\left(Y_{t}^{k}, X_{t}^{k}\right) \text { is feasible }\right\}
$$

The idea behind the metafrontier is that all $\mathrm{L}_{\mathrm{t}}^{\mathrm{k}}$ sets belong to a common unrestricted technology set $\mathrm{L}^{*}$ :

$$
L_{t}^{*}=\left\{L_{t}^{1} \cup L_{t}^{2} \cup L_{t}^{3} \cup \ldots \ldots \cup L_{t}^{k}\right\}
$$

to which each of the $k$ groups has potential access.

The metafrontier is defined as the boundary of this unrestricted technology set and it is derived as the envelope of the group frontiers, identifying a metatechnology that is assumed to be available to all the firms in the sample.

In SFA the metafrontier is estimated by linear or quadratic programming (Battese 2004) as an overarching function that envelops the single group frontiers. Define

$$
C_{i t}^{k}=f\left(X_{i t} \beta^{k}\right) \exp \left(v_{i t}^{k}+u_{i t}^{k}\right)=\exp \left(X_{i t} \beta^{k}\right) \exp \left(v_{i t}^{k}+u_{i t}^{k}\right)
$$

as the $k$-th group cost frontier, depending on the matrix of independent variables $X$ and a vector of group specific parameters $\beta^{k}$. The metafrontier can be defined as the envelope of the $k$ estimations of (6) as

$$
C_{i t}^{*}=f\left(X_{i t} \beta^{*}\right)=\exp \left(X_{i t} \beta^{*}\right)
$$


So it has the same functional form of (6) with a vector of parameters $\beta^{*}$ that has to be estimated subject to the constraint that

$X_{i t} \beta^{*} \leq X_{i t} \beta^{k}$

That is the meta cost technology gives the minimum possible cost available among all the groups.

Equation (7) can be estimated by linear programming, hence solving

$\operatorname{Min} \mathrm{L}=\sum_{i=1}^{N} \sum_{t=1}^{T}\left(X_{i t} \hat{\beta^{k}}-X_{i t} \beta^{*}\right)$

subject to (8). ${ }^{15}$ The radial distance of each unit from the metafrontier is called metaefficiency and it is defined as

$$
E F F_{i t}^{*}=\frac{\exp \left(X_{i t} \beta^{*}\right) \exp \left(v_{i t}^{k}\right)}{C_{i t}^{k}}
$$

which given (6) is equivalent to

$$
E F F_{i t}^{*}=\exp \left(-u_{i t}^{k}\right) \frac{\exp \left(X_{i t} \beta^{*}\right)}{\exp \left(X_{i t} \beta^{k}\right)}
$$

Equation (11) means that the metaefficiency of firm $i$ of group $k$ at time $t$ is made of two parts: the first is its group specific cost efficiency $E F F_{i t}^{k}=\exp \left(-u_{i t}^{k}\right)$, with $0 \leq E F F_{i t}^{k} \leq 1$. The second is known as technological gap ratio (TGR), and it measures the distance between the metafrontier and the group specific frontier; TGR $\leq 1$ with higher values indicating a closer proximity to the metafrontier and lower values indicating a larger gap between the two. Empirically one would first estimate $\mathrm{EFF}^{\mathrm{k}}$ and TGR and compute $\mathrm{EFF}^{*}$ subsequently as their product. 
In DEA, which is already a linear programming technique, the estimation of a metafrontier is the estimation of a general unrestricted frontier using all the group data together. Similarly to SFA also in DEA we will have $T G R_{i t}=\frac{E F F_{i t}^{*}}{E F F_{i t}^{k}}$.

Coming finally to the calculation of TFP change, this has to be based upon the metafrontier results. For the Divisia index we perform the calculations in (5) using the estimated coefficients from the metafrontier obtained from (9) and (8). Given the specification of (10) and to avoid double counting of technological progress the cost efficiency measure used in the Divisia has to remain the group-specific cost efficiency.

The metafrontier Malmquist index is computed as in (2) but using the metatechnology as a reference point so that

$$
\begin{gathered}
M *\left(X_{t+1}, Y_{t+1}, X_{t}, Y_{t}\right)=\left[\frac{D_{v, t}^{*}\left(X_{t}, Y_{t}\right)}{D_{v, t+1}^{*}\left(X_{t+1}, Y_{t+1}\right)}\right] *\left[\frac{D_{v, t+1}^{*}\left(X_{t}, Y_{t}\right)}{D_{v, t}^{*}\left(X_{t}, Y_{t}\right)} \frac{D_{v, t+1}^{*}\left(X_{t+1}, Y_{t+1}\right)}{D_{v, t}^{*}\left(X_{t+1}, Y_{t+1}\right)}\right]^{1 / 2} * \\
*\left[\frac{D_{c, t+1}^{*}\left(X_{t}, Y_{t}\right)}{D_{v, t+1}^{*}\left(X_{t}, Y_{t}\right)} \frac{D_{v, t+1}^{*}\left(X_{t+1}, Y_{t+1}\right)}{D_{c, t+1}^{*}\left(X_{t+1}, Y_{t+1}\right)} \frac{D_{c, t}^{*}\left(X_{t}, Y_{t}\right)}{D_{v, t}^{*}\left(X_{t}, Y_{t}\right)} \frac{D_{v, t}^{*}\left(X_{t+1}, Y_{t+1}\right)}{D_{c, t}^{*}\left(X_{t+1}, Y_{t+1}\right)}\right]^{1 / 2} \\
=E C^{*} * T C^{*} * S C^{*}
\end{gathered}
$$

\section{Empirical results}

To test whether the various ownership types are operating under the same technology and therefore the data can be pooled under a single frontier, we used both parametric and nonparametric techniques: t-test, Mann-Whitney, Kruskall-Wallis (KW) test and KolmogorovSmirnov (KS) test for DEA, as well as an LR test in SFA (Aly et al., 1990; Elyasiani and Mehdian, 1990; Isik and Hassan, 2002). The results are reported in Table A1 in the appendix and show that the null hypothesis of a common technology is generally rejected, leading us to 
conclude that it is appropriate to construct cost efficiency frontiers separately for each ownership group.

\section{A. Ownership specific analysis of Total Factor Productivity}

The first part of the analysis therefore consists of estimating ownership-specific frontiers and their TFP changes and components. For the parametric analysis, we follow Battese and Coelli (1995) and estimate equations (3) and (4) simultaneously with a Maximum Likelihood onestep procedure. Linear homogeneity of degree one in input prices and Young's symmetry are imposed prior to estimation. In the non-parametric analysis, we follow a sequential Data Envelopment Analysis approach (Tulken and Vanden Eeckaut, 1995). This particular approach assumes that technical knowledge accumulates over time hence implying dependence in the production process; this reduces the wide oscillations typical of DEA as the frontier will be moving forward in the presence of technical progress and remain static otherwise. The use of sequential DEA should improve the comparability of the two methodologies. Nonetheless, due to the fundamental characteristics of the two approaches, we would expect the DEA results to be more extreme and, in the presence of technological progress, to show larger technology changes than efficiency changes.

The most important things to notice about this initial part of the analysis are that the SFA coefficients and elasticities have the expected signs, inefficiency is significant for all ownerships, whilst the passing of time and the introduction of re-regulation have mixed effects on the technological choices of the three ownerships. ${ }^{16}$ Furthermore, foreign banks show an increase in the optimal scale of production of performing loans and a decrease in that of other earning assets, contrary to both private and state banks. This is consistent with the removal of restrictions on their operations, which progressively allowed foreign banks to increasingly familiarise themselves with the local loans market. As illustrated in Table 3, 
both SFA and DEA show high average levels of efficiency (about 90\%) that slightly worsen after re-regulation; these results are not significantly different between the two methodologies, with the exception of private banks which DEA ranks as remarkably less efficient than SFA. ${ }^{17}$

\section{<Insert Table 3>}

Moving on to the measurement of productivity, as we can see in Table 4 TFP overall is increasing over time, and the difference between the DEA Malmquist and the SFA Divisia is not statistically significant; the only difference between the two methodologies is in the estimates of technology change, but the general trends and the actual change rates of TFP are not statistically different. ${ }^{18}$ This improvement is mainly due to improvements in technology, with DEA recording as expected higher values than SFA.

\section{<Insert Table 4>}

These ownership-specific results do now allow us to draw any inference at the industry level. Therefore, to compare results across ownership groups we move on to compute estimates relative to a metafrontier.

\section{B. Metafrontier analysis of Total Factor Productivity}

We estimate metafrontiers using both DEA and SFA techniques, followed by a generalised sequential metafrontier Malmquist index and a metafrontier Divisia index. To allow a more flexible modelling of the passing of time on technology in SFA we estimate two separate metafrontiers, one for 1992-1997 and one for the 1998-2009. ${ }^{19}$

The coefficients of the two SFA-based metafrontiers are reported in Table A3 in the appendix. Tables 5 and 6 report the metafrontier Divisia index results and the metafrontier Malmquist index results derived from SFA and DEA respectively.

\section{<Insert Table 5 and 6>}


The results are very consistent across methodologies, all the comparable series are not significantly different at a 5\% level (except from scale changes) and find an increase in overall TFP especially after 1998. If we do not take into account the environmental factors in the Divisia index the figures are even closer (refer to column TFP2 in Table 5), with an overall average yearly improvement between $0.4 \%$ and $1.4 \%$ before 1998 and increasing to about $3 \%$ per year afterwards. The main contributor to these TFP changes is always technological progress. As expected, in DEA this is more marked and translates into a worsening of efficiency, whereas SFA gives lower technical improvements and marginally positive efficiency changes. Finally, the scale component worsens in all cases, going from mildly increasing returns to scale pre-1997 to mildly decreasing returns to scale post 1998 .

\section{Metaefficiency and Technology Gap Ratios}

The metafrontier framework allows us to decompose differences in overall performance (metaefficiency) into cost efficiency and technology gap ratio (TGR), where the TGR measures the distance between the group frontiers and the metafrontier. ${ }^{20}$ While cost efficiency relates mainly to the performance of a firm's management, the TGR represents the nature of the production environment (O'Donnell et al., 2008). In this context, regulatory changes influence the environmental characteristics of the market; therefore an analysis of technology gaps can provide important information on the outcomes of the deregulation process.

Table 7 reports the average technology gap ratios (TGR), cost efficiency and metaefficiency scores for the whole industry and the different ownerships, for DEA and SFA. Table 7 shows that industry technology improves over time, as indicated by the widening gap between the metafrontier and the single ownership frontiers (the decreasing TGR values). ${ }^{21}$ In particular, while before 1998 state banks are the sector leaders in terms of technology and 
metaefficiency, after 1998 they lose technological leadership in favour of foreign banks. This is true for both DEA and SFA.

\section{<Insert Table 7>}

This improvement in the position of foreign banks is confirmed when we look at individual data points and calculate the number and sample proportion of technology leaders for each ownership. In this context, we define technology leaders or innovators those banks with a TGR $=1$, i.e. those which are using the best available technology. This is shown in Table 8 where again we can see the increasingly dominant position of foreign banks after $1998{ }^{22}$

\section{<Insert Table 8>}

To corroborate these results, in Figures 1 and 2 we present the histograms and kernel density estimations of technology gap ratios for the three ownership types, separately for the periods 1992-1997 and 1998-2009.

\section{$<$ Insert Figures 1 and 2>}

The figures quite clearly show how the TGR distribution changes after 1998, with state banks in particular losing their lead position whilst the concentration of leaders for foreign banks becomes higher than for the rest of the sample.

\section{Catch up Index}

Whilst very informative, the TGR is a static measure of leadership. To look further into the issue of technological leadership we follow Chen and Yang (2011) and construct a catch-up index, given by the ratio of the technical change of the $i$-th bank against the metafrontier $\left(T C_{i t}^{*}\right)$ to its technical change against the $k$-th ownership frontier $\left(T C_{i t}^{k}\right)$, that is:

$$
C U_{i t}=\frac{T C_{i t}^{*}}{T C_{i t}^{k}}
$$


$C U$ therefore measures the dynamics of the changes in technological leadership among different ownership types, with lower values indicating a speeding of the catch up process and viceversa. The results are reported in Table 9; they are not significantly different between DEA and SFA and indicate that the best practices among foreign banks are narrowing their technical gap at a faster speed than state or private banks. The speed of the catch up process decreases over time for all ownership types. State banks appear to be the slowest in the sample in terms of catching up with the best available technology.

The overall picture therefore seems to indicate that the change in regulatory regime generated a very favourable environment for the best practices of foreign banks to use the best available technology and engage in cost technology innovation.

\section{<Insert Table 9>}

\section{Further robustness and convergence test}

Finally, to check on the robustness of the above conclusion we test for the convergence of the ownership specific frontiers towards the metafrontier, based on a reduced form of their respective dynamic processes (see for example Thirtle et al., 2003). Define $T C_{t}^{k}$ the change of technology of the $k$-th ownership frontier at time $t, T C_{t}^{*}$ the change of technology of the metafrontier at time $t$, and assume that the growth processes are given by:

$\ln T C_{t}^{k}=\gamma_{k}+\lambda \ln \left(\frac{T C^{*}{ }_{t-1}}{T C_{t-1}^{k}}\right)+\ln T C_{t-1}^{k}+\varepsilon_{t}$

and

$\ln T C^{*}{ }_{t}=\gamma^{*}+\ln T C^{*}{ }_{t-1}+\eta_{t}$ 
where $\gamma_{\mathrm{k}}$ and $\gamma^{*}$ are the asymptotic growth rates of $T C^{k}$ and $T C^{*}$ respectively and $\lambda$ measures the speed of catch up between them. Combining (14) and (15) we get:

$$
\ln \left(\frac{T C_{t}^{k}}{T C^{*}{ }_{t}}\right)=\left(\gamma_{k}-\gamma^{*}\right)+(1-\lambda) \ln \left(\frac{T C_{t-1}^{k}}{T C^{*}{ }_{t-1}}\right)+\phi_{t}
$$

We estimate (16) for each of the ownership types, using both DEA and SFA results, and conduct an $\mathrm{ADF}$ test to check for the presence of a unit root; namely the presence of a unit root $(\lambda=0)$ implies that there is no technological spill-over between the metafrontier and the ownership specific frontiers. Conversely the difference between them will be stationary if the null hypothesis of a unit root is rejected and $\lambda>0$, with full convergence found if also the intercept $\left(\gamma_{\mathrm{k}}-\gamma^{*}\right)$ is not significantly different from 0 .

The results of the tests are reported in Table 10 and indicate that only the frontier of foreign banks converges consistently across methodologies towards the metafrontier in the long run. This confirms our conclusion that the metafrontier is led by foreign banks and suggests a lack of significant technological spillovers between ownerships.

\section{<Insert Table 10>}

\section{Conclusion}

The main aim of this study is to assess the impact of regulatory reform on TFP growth and its sources and on the ownership-performance relationship for the case of Indian banks. We do so by implementing a novel methodological framework which leads to the estimation of TFP by means of a non-parametric sequential metafrontier Malmquist index and a parametric metafrontier Divisia index.

Guided by two Narasimham Committee reports (in 1991 and 1998 respectively), the Indian Government introduced a series of financial sector reforms which fostered a uniform regulatory framework, theoretically creating a market with a level playing field. Despite the 
fact that nearly two decades have passed since the first Narasimham Committee report, we find evidence of continued heterogeneity across the industry. Departing from the existing literature on efficiency and productivity measurement, we explicitly tested and rejected the assumption of the existence of a common production technology, leading us to construct cost efficiency frontiers separately for each ownership type. Both DEA and SFA results indicate relatively high levels of efficiency, which worsen after 1998. Results are consistent across methodologies for state-owned and foreign banks. Private banks are however a very heterogeneous group; they experience the largest number of entries (particularly post 1996) as well as exits or M\&As. Research shows that the performance of firms entering the market is normally below that of the average incumbent. When new small firms enter and exit the market, the variance of the distribution is likely to increase and this can explain the lower efficiency of private banks measured by DEA compared to SFA. Overall productivity, measured both by the DEA Malmquist and the SFA Divisia, is increasing over time. Consistently with previous literature, we find that this improvement is mainly due to improvements in technology.

To be able to compare the results across ownership types, we estimate a generalised sequential metafrontier Malmquist index and a metafrontier Divisia index. Again, the overall TFP is positive and mainly driven by technological progress. Results also indicate that different ownership types reacted differently to changes in policy and to the operating environment. In particular, changes in regulatory regime generated a very favourable environment for foreign banks, which enabled them to use the best available technology in the industry and engage in cost technology innovation. The position of foreign banks becomes increasingly dominant over time and their production technology is becoming the best available technology in the industry. This is consistent with the removal of restrictions on their operations, which progressively allowed foreign banks to increasingly familiarise 
themselves with the local loans market. Foreign banks seem to have capitalised on the relative advantages of their asset portfolio. On the other hand, the increasing technological gap between the best practice and the private and state banks frontier indicates a lack of significant technological spillovers. To conclude, financial reforms have benefited the Indian banking sector and resulted in sustained productivity growth. However, the benefits of reforms have not being uniformly distributed across ownership types, with state-owned banks losing the ability to act as undisputed industry leaders as well as losing customers and market share. An interesting extension to the current study would be a micro level analysis of the characteristics and determinants of ownership differences, with particular focus on bank risk. 


\section{APPENDIX}

Table A1: Summary of parametric and nonparametric tests for the null hypothesis of a common technology among different ownership groups.

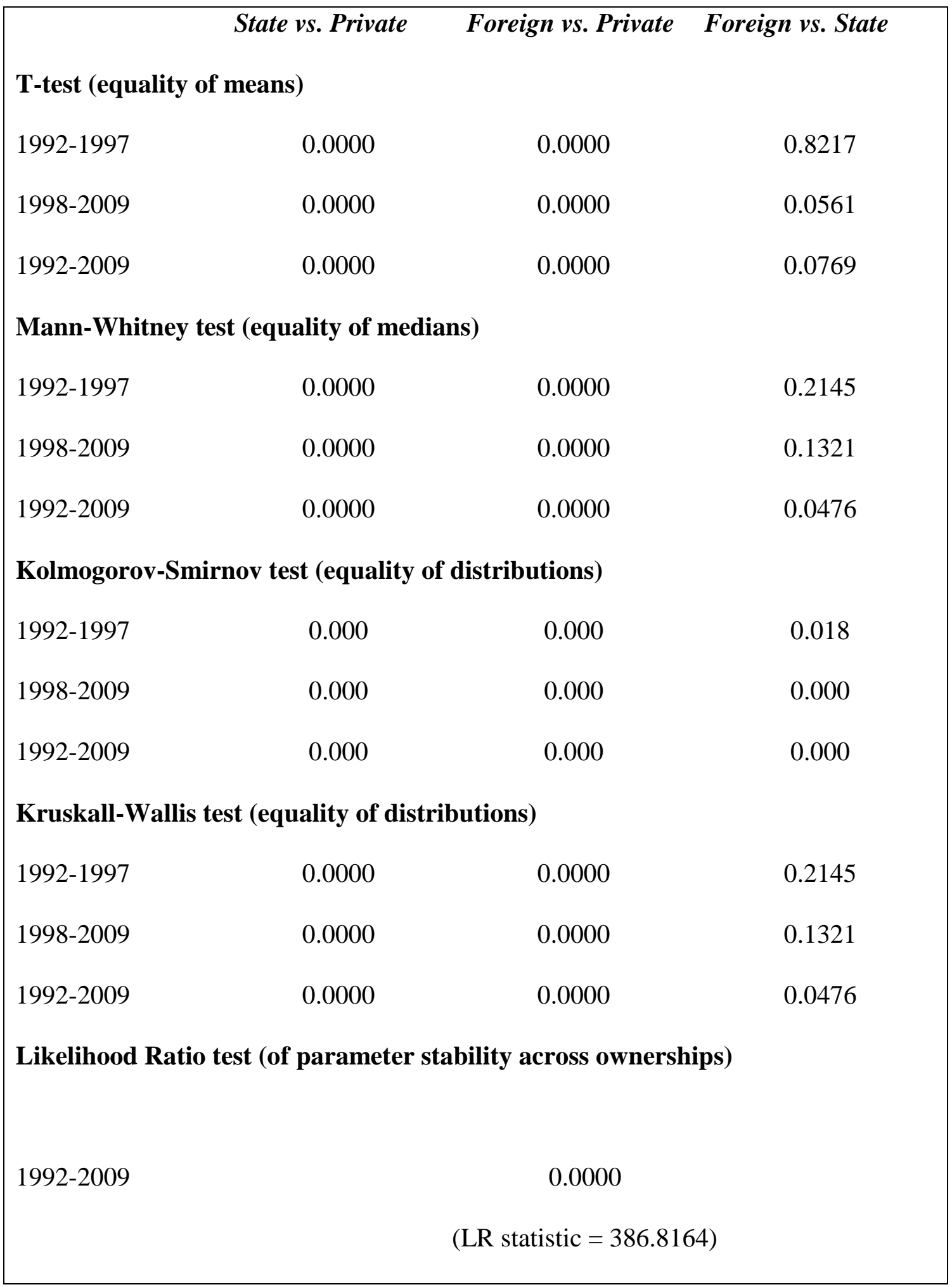

Note: the figures are the p-values associated with each test. 
Table A2: Key results from the estimation of the group specific SFA frontiers

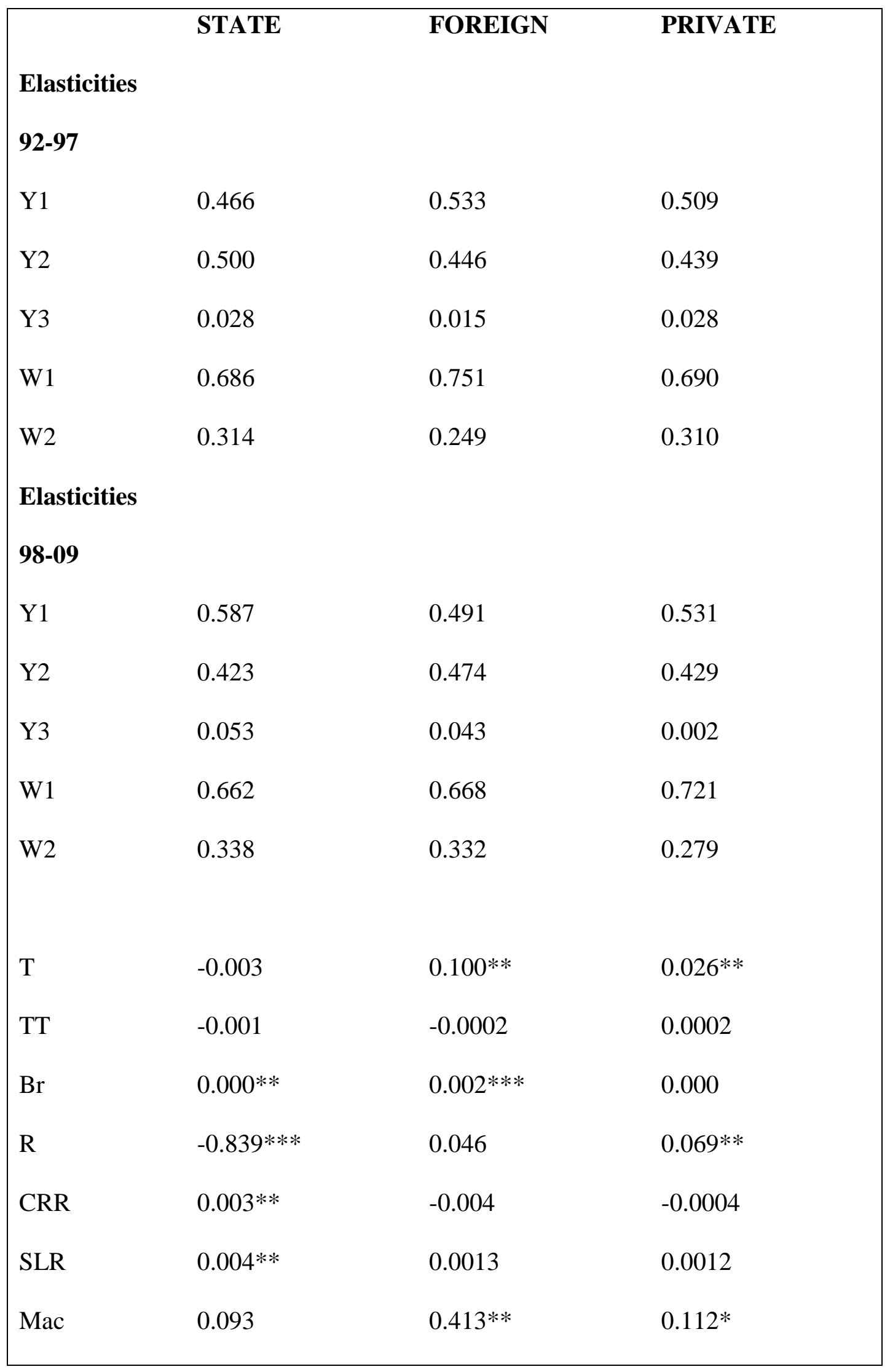




\begin{tabular}{|llll|}
\hline Inefficiency & & & \\
Const & $0.057 * *$ & - & 0.00 \\
$\mathrm{R}$ & $0.167 *$ & - & 0.066 \\
$\mathrm{~T}$ & 0.016 & - & -0.005 \\
$\mathrm{TT}$ & $-0.002 * * *$ & - & -0.001 \\
$\mathrm{O} / \mathrm{n}$ & - & - & -0.183 \\
$\mathrm{O} / \mathrm{nR}$ & - & $\mathbf{1 9 8 . 1 3 9}$ & 0.100 \\
Loglk & $\mathbf{8 9 5 . 2 1 7}$ & $\mathbf{0 . 0 2 9}$ & $\mathbf{6 8 0 . 9 9 8}$ \\
Sigmasq & $\mathbf{0 . 0 0 3}$ & $\mathbf{0 . 8 7 3 3 * * *}$ & $\mathbf{0 . 0 1 8}$ \\
Gamma & $\mathbf{0 . 8 2 8 * * *}$ & $\mathbf{0 . 9 2 6 * * *}$ \\
\hline
\end{tabular}

$\mathrm{O} / \mathrm{n}$ is a dummy taking value 1 for "old" private banks who were in business prior to 1995 , and 0 otherwise. 
Table A3: Results from the estimation of the SFA Metafrontier

\begin{tabular}{|c|c|c|}
\hline & 1992-1997 & 1998-2009 \\
\hline Const & 4.373 & 9.448 \\
\hline $\ln Y 1$ & -0.142 & -0.779 \\
\hline $\ln Y 2$ & 0.848 & 1.099 \\
\hline $\ln Y 3$ & -0.009 & -0.078 \\
\hline $\ln P^{*}$ & 0.312 & 0.023 \\
\hline $\ln Y 1 \ln Y 1$ & 0.049 & 0.021 \\
\hline $\ln Y 2 \ln Y 2$ & 0.014 & -0.046 \\
\hline $\ln Y 3 \ln Y 3$ & -0.004 & -0.005 \\
\hline $\ln P * \ln P *$ & 0.123 & 0.202 \\
\hline $\ln Y 1 \ln Y 2$ & -0.057 & 0.040 \\
\hline $\ln Y 1 \ln Y 3$ & 0.005 & 0.000 \\
\hline $\ln Y 2 \ln Y 3$ & 0.002 & 0.013 \\
\hline $\ln Y 1 \ln P^{*}$ & 0.016 & 0.104 \\
\hline $\ln Y 2 \ln P *$ & -0.031 & -0.079 \\
\hline $\ln Y 3 \ln P^{*}$ & 0.027 & -0.008 \\
\hline$T$ & -0.108 & -0.076 \\
\hline$T T$ & -0.002 & 0.003 \\
\hline $\ln Y 1 T$ & -0.024 & -0.008 \\
\hline $\ln Y 2 T$ & 0.039 & 0.014 \\
\hline $\ln Y 3 T$ & -0.011 & -0.007 \\
\hline $\ln P * T$ & 0.003 & -0.014 \\
\hline$B r$ & 0.00001 & 0.00001 \\
\hline$C R R$ & 0.003 & -0.014 \\
\hline
\end{tabular}




\begin{tabular}{|lcc|}
\hline SLR & 0.003 & -0.049 \\
Mac & 0.256 & 0.28 \\
\hline
\end{tabular}




\section{REFERENCES}

Aigner, Dennis, Lovell, Knox., Schmidt, Peter. "Formulation and estimation of stochastic frontier production models", Journal of Econometrics 6 (1977), 21-37.

Aly, Hassan.Y., Grabowski, Richard, Pasurka, Carl and Rangan, Nanda, "Technical, Scale and Allocative Efficiencies in U.S. banking: An Empirical Investigation", Review of Economics and Statistics 72 (1990), 211-218.

Battese, George. E., Coelli, Tim. J., "A model for technical inefficiency effects in a stochastic frontier production function for panel data", Empirical Economics 20 (1995), 325-332.

Battese, George. E., Rao, Prasada D.S., O' Donnell, Christopher J., "A metafrontier production function for estimation of technical efficiencies and technology gaps for firms operating under different technologies", Journal of Productivity Analysis 21 (2004), 91-103. Bauer, Paul W., Berger, Allen N., Ferrier, Gary D., Humphrey, David B., "Consistency conditions for regulatory analysis of financial institutions: a comparison of frontier efficiency methods", Journal of Economics and Business 50, (1998), 85-114.

Berger Allen N., "International comparisons of banking efficiency," Financial Markets, Institutions and Instruments, 16, (2007), 119-44.

Berger Allen N., Humphrey, D. D., "Efficiency of Financial Institutions: International Survey and Directions for Future Research," European Journal of Operational Research, 98, (1997), 282-94.

Berger, Allen N., Klapper, Leora F., Peria, Maria Sledad M., Zaidi, Rida, "Bank ownership type and banking relationships", Journal of Financial Intermediation 17 (2008), 37-62.

Bonaccorsi di Patti, Emilia, Hardy, Daniel, "Financial sector liberalization, bank privatization, and efficiency: evidence from Pakistan”, Journal of Banking and Finance 29, (2005), 2381-2406. 
Bhattacharyya, Arunava, Lovell C.A. Knox , Sahay, Pankaj, “The Impact of Liberalisation on the Productive Efficiency of Indian Commercial Banks", European Journal of Operations Research, 98, (1997), 332-345.

Bhaumik, Sumon K., Dimova, Ralitza D., "How Important is Ownership in a Market with Level Playing Field? The Indian Banking Sector Revisited", Journal of Comparative Economics, 32, (2004), 165-180.

Bhaumik, Sumon K., Dang, Vinh, Kutan, Ali M., "Implications of bank ownership for the credit channel of monetary policy transmission: evidence from India", Journal of Banking and Finance, 35, 9 (2011), 2418-2428.

Bos, Jaap W.B., Schmiedel, Heiko, "Is there a single frontier in a single European banking market?", Journal of Banking and Finance 31, (2007) 2081-2102.

Casu, Barbara, Girardone, Claudia, Molyneux, Phil, "Productivity change in European banking: a comparison of parametric and non-parametric approaches", Journal of Banking and Finance 28, (2004), 2521-2540.

Charnes, Abraham, Cooper, William W., Rhodes, E., "Measuring the efficiency of decision making units”, European Journal of Operational Research 2 (1978), 429-44.

Charnes, Abraham, Cooper, William W., Rhodes, E., "Evaluating program and managerial efficiency: an application of Data Envelopment Analysis to program follow through", Management Science 27 (1981), 668-697.

Chen Ku-Hsieh., Yang, Hao-Yen., “A cross-country comparison of productivity growth using the generalized metafrontier Malmquist productivity index: with application to banking industries in Taiwan and China”, Journal of Productivity Analysis, 35,3 (2011), 197-212.

Cole, Shawn, "Financial development, bank ownership, and growth: or, does quantity imply quality?", The Review of Economics and Statistics, 91(2009) 33-51. 
Cook, Wade D., Seiford Larry M., "Data Envelopment Analysis (DEA) - Thirty Years on", European Journal of Operational Research, 192(1), (2009), 1-17.

Das, A. and Ghosh, S., "Financial Deregulation and Efficiency: An Empirical Analysis of Indian Banks During the Post-Reform Period," Review of Financial Economics, 15, (2006), 193-221.

Das, Abhiman and Ghosh, Saiman, "Financial Deregulation and Profit Efficiency: A NonParametric Analysis of Indian Banks", Journal of Economics and Business, 61, (2009), 509528.

Denny, Abraham., Fuss, Melvyn, Waverman, Leonard, "The measurement and interpretation of total factor productivity in regulated industries, with an application to Canadian telecommunications"; in Cowing, T.G.., Stevenson, R.E. (Eds.), Productivity Measurement in Regulated Industries. New York: Academic Press, (1981).

Elyasiani, Elyas, Mehdian, Seyed M., "Productive Efficiency Performance of Minority and Non-Minority Owned Banks: A Non-Parametric Approach," Journal of Banking and Finance 16 (1992), 933-948.

Färe, Rolf, Grosskopf, Shawna, Lindgren, Bjorn, Roos, Paul, "Productivity developments in Swedish hospitals: a Malmquist output index approach"; in Charnes Abraham, Cooper, William W., Lewin, Arie Y., Seiford. Lawrence M.: Data Envelopment Analysis: Theory, Methodology and Applications Boston: Kluwer Academic Publishers, (1994).

Fried, Harold O., Lovell, C.A. Knox, Schmidt Shelton S, The Measurement of Productive Efficiency and Productivity Growth, Oxford: Oxford University Press (2008).

Isik, Ihsan, Hassan, Kabir, "Financial deregulation and total factor productivity change: an empirical study of Turkish commercial banks", Journal of Banking and Finance 27 (2003), $1455-1485$. 
Goddard, John A., Molyneux, Phil, Wilson, John O. S., European Banking: Efficiency, Technology and Growth, London, John Wiley and Sons, (2001).

Goddard, John A., Molyneux, Phil, Wilson, John O. S., Tavakoli, Manouche, "European banking: an overview", Journal of Banking and Finance, 31, (2007), 1911-35.

Hughes, Joseph P., Mester, Loretta J., "Efficiency in banking: theory, practise and evidence." In Berger Allen, Molyneux, Phil and John O.S. Wilson (Eds.) The Oxford Handbook of Banking, (2010) Oxford University Press, Oxford.

Kontolaimou, Alexandra, Tsekouras, Kostas, "Are cooperatives the weakest link in European banking? A non-parametric metafrontier approach", Journal of Banking and Finance 34 (2010), 1946-1957.

Koetter, Michael, Poghosyan, Tigran, "The identification of technology regimes in banking: Implications for the market power-fragility nexus", Journal of Banking and Finance 33 (2009) 1413-1422.

Kumbhakar, Subal C., Lovell, C.A. Knox, Stochastic Frontier Analysis, Cambridge University Press, (2003).

Kumbhakar, Subal. C., Sarkar, Subrata, "Deregulation, ownership and productivity growth in the banking industry: evidence from India", Journal of Money, Credit, and Banking 35, (2003), 403-414.

Kumbhakar, Subal C., Lozano-Vivas, Ana, "Deregulation and productivity: the case of Spanish banks”, Journal of Regulatory Economics 27 (2005), 331-351.

Leightner, Jonathan E., Lovell, C.A. Knox, "The impact of financial liberalization on the performance of Thai banks", Journal of Economics and Business 50, (1998), 115-131.

Malmquist, Sten, "Index numbers and indifference surfaces", Trabajos de Estatistica, 4, (1953), 209-242. 
Meeusen Wim, Van den Broek, Julien, "Efficiency estimations from Cobb-Douglas production functions with composed error", International Economic Review 18 (1977), 435444.

Mukherjee, Kankana, Ray, Subash C., Miller, Stephen M., "Productivity growth in large US commercial banks: the initial post-deregulation experience", Journal of Banking and Finance 25, (2001), 913-939.

Narasimhan Committee Report, Report of the Committee on the Financial Sector Reforms; New Delhi: Ministry of Finance, (1991 and 1998).

O’Donnell, Cristopher J., Rao, D.S. Prasada., Battese, George E., "Metafrontier frameworks for the study of firm-level efficiencies and technology ratios", Empirical Economics 34 (2008), 231-255.

Ray, Subash .C., Desli, Evangelia, "Productivity growth, technical progress, and efficiency change in industrialised countries: a comment", American Economic Review 87, (1997), $1033-1039$.

Ray, Subash C. and Das, Abhiman, "Distribution of Cost and Profit Efficiency: Evidence from Indian Banking,” European Journal of Operational Research, 201, (2010), 297-307.

Sathye, Milind, "Efficiency of Banks in a Developing Economy: The Case of India", European Journal of Operational Research, 148, (2003), 662-671.

Sealey, Calvin W., Lindley, James T., "Inputs, outputs and a theory of production and cost at depository financial institutions", Journal of Finance 32 (1977), 1251-1266.

Sensarma, Rudra, "Are Foreign Banks Always the Best? Comparison of State-Owned, Private and Foreign Banks in India”, Economic Modelling, 23, (2006), 717-735.

Shephard, Ronald W., Cost and Production Functions. Princeton: Princeton University Press, (1953). 
Shephard, Ronald W., The theory of Cost and Production Functions, Princeton: Princeton University Press, (1970).

Stein, Jeremy C., "An adverse-selection model of bank asset and liability management with implications for the transmission of monetary policy", RAND Journal of Economics, 29, (1998) 466-486.

Stein, Jeremy C., "Information production and capital allocation: Decentralized vs. hierarchical firms", Journal of Finance 57 (2002), 1891-1921.

Sturm, Jan-Egbert, Williams, Barry, "Foreign bank entry, deregulation and bank efficiency: lessons from the Australian experience", Journal of Banking and Finance 28 (2004), 17751799.

Tulken, Henry, Vanden Eeckaut, Philippe, "Non-parametric efficiency, progress and regress measures for panel data: methodological aspects", European Journal of Operational Research 80 (1995), 474-499.

Thirtle, Colin, Piesse, Jennifer, Luigi, Angela, Suhariyanto, Kecuk., "Multi-factor agricultural productivity, efficiency and convergence in Botswana, 1981-1996", Journal of Development Economics 71 (2003), 605-624.

Zhao, Tianshu, Casu, Barbara, Ferrari, Alessandra, "The impact of regulatory reforms on cost structure, ownership and competition in Indian banking", Journal of Banking and Finance 34 (2010), 246-254.

Zhou, Xianming, "Understanding the determinants of managerial ownership and the link between ownership and performance: comment", Journal of Financial Economics 62 (2001), 559-571. 
Table 1: Number of banks relative weight of different ownerships

\begin{tabular}{|lccccccc|}
\hline & \multicolumn{3}{c}{ Number of banks } & \multicolumn{3}{c|}{ Proportion of total assets } \\
& State & Foreign & Private & Industry & State & Foreign & Private \\
$\mathbf{1 9 9 2}$ & 27 & 13 & 23 & 0.986 & 0.89 & 0.07 & 0.04 \\
$\mathbf{1 9 9 8}$ & 27 & 15 & 32 & 0.988 & 0.82 & 0.08 & 0.10 \\
$\mathbf{2 0 0 9}$ & 27 & 13 & 22 & 0.994 & 0.72 & 0.08 & 0.20 \\
\hline
\end{tabular}

Note: The column industry reports the proportion of total assets of our sample over the whole industry. 
Table 2: Inputs and outputs summary statistics (1992-2009)

\begin{tabular}{|cccccc|}
\hline Variable & Mean & Median & Min & Max & Stdev \\
$\mathrm{TC}$ & 10261 & 4182 & 12.67 & 250381 & 21005 \\
$\mathrm{y}_{1}$ & 66129 & 20522 & 48.48 & 2277632 & 151871 \\
$\mathrm{y}_{2}$ & 45929 & 16333 & 31.98 & 1179795 & 98846 \\
$\mathrm{y}_{3}$ & 2000 & 775 & 0.621 & 54257 & 4402 \\
$\mathrm{w}_{1}$ & 0.073 & 0.068 & 0.004 & 0.812 & 0.069 \\
$\mathrm{w}_{2}$ & 0.027 & 0.025 & 0.002 & 0.281 & 0.023 \\
\hline
\end{tabular}

Note: $\mathrm{TC}=$ total operating cost; $\mathrm{y}_{1}$ : performing loans; $\mathrm{y}_{2}:$ other earning assets; $\mathrm{y}_{3}$ : fee-based income; $\mathrm{w}_{1}$ : loanable funds price; $\mathrm{w}_{2}=$ non-operating cost price. Cost and outputs are in Rs mil and deflated using 1994 as the base year. 
Table 3: Yearly average efficiency scores

\begin{tabular}{|ccccccc|}
\hline & \multicolumn{2}{c}{ STATE } & \multicolumn{2}{c}{ FOREIGN } & \multicolumn{2}{c|}{ PRIVATE } \\
& SFA & DEA & SFA & DEA & SFA & DEA \\
$\mathbf{1 9 9 2 - 1 9 9 7}$ & 0.923 & 0.910 & 0.888 & 0.906 & 0.945 & 0.692 \\
$\mathbf{1 9 9 8 - 2 0 0 9}$ & 0.922 & 0.891 & 0.884 & 0.866 & 0.945 & 0.628 \\
$\mathbf{1 9 9 2 - 2 0 0 9}$ & 0.922 & 0.897 & 0.885 & 0.880 & 0.945 & 0.649 \\
\hline
\end{tabular}


Table 4: Total Factor Productivity Change

\begin{tabular}{|c|c|c|c|c|c|c|c|c|}
\hline \multirow{3}{*}{ STATE } & \multicolumn{2}{|c|}{ TFP $^{\mathrm{k}}$} & \multicolumn{2}{|c|}{$T C^{k}$} & \multicolumn{2}{|c|}{$E C^{k}$} & \multicolumn{2}{|c|}{$\mathrm{SC}^{\mathrm{k}}$} \\
\hline & Divisia & Malmq & Divisia & Malmq & Divisia & Malmq & Divisia & Malmq \\
\hline & & & & & & & & \\
\hline $92-09$ & 0.999 & 1.021 & 1.003 & 1.051 & 1.001 & 0.985 & 0.995 & 0.993 \\
\hline $92-97$ & 0.998 & 1.012 & 1.01 & 1.041 & 1.000 & 0.980 & 1.00 & 0.985 \\
\hline 98-09 & 0.999 & 1.025 & 1.001 & 1.055 & 1.002 & 0.987 & 0.993 & 0.988 \\
\hline FORE & & & & & & & & \\
\hline $92-09$ & 1.071 & 1.048 & 1.051 & 1.116 & 1.002 & 0.985 & 0.999 & 0.956 \\
\hline $92-97$ & 1.070 & 1.045 & 1.049 & 1.132 & 1.003 & 0.973 & 1.002 & 0.958 \\
\hline 98-09 & 1.071 & 1.049 & 1.052 & 1.110 & 1.001 & 0.989 & 0.997 & 0.955 \\
\hline PRIVA & & & & & & & & \\
\hline $92-09$ & 1.024 & 1.029 & 1.015 & 1.095 & 1.001 & 0.972 & 1.005 & 0.965 \\
\hline $92-97$ & 1.029 & 1.074 & 1.013 & 1.165 & 0.998 & 0.968 & 1.005 & 0.957 \\
\hline 98-09 & 1.022 & 1.011 & 1.016 & 1.067 & 1.002 & 0.974 & 1.005 & 0.969 \\
\hline
\end{tabular}

Note: The superscript $\mathrm{k}$ indicates results obtained with reference to group specific frontiers.

$\mathrm{TFP}=$ total factor productivity $; \mathrm{TC}=$ technical change; $\mathrm{EC}=$ efficiency change; $\mathrm{SC}=$ scale change. Along with TFP the table reports only the 3 components of the Divisia index directly comparable with the Malmquist index: technical change, efficiency change and scale change. The Divisia values have been transformed from change rates into changes to make the comparison with the Malmquist possible. 
Table 5: Metafrontier Divisia Index

\begin{tabular}{|c|c|c|c|c|c|c|c|c|}
\hline & $S C^{*}$ & $T C^{*}$ & $E X^{*}$ & $A L L C^{*}$ & $E C^{*}$ & $M U^{*}$ & $T F P^{*}$ & TFP2 \\
\hline $92-93$ & 0.998 & 1.008 & 0.968 & 1.007 & 0.985 & 1.001 & 0.967 & 0.999 \\
\hline $93-94$ & 0.995 & 1.006 & 1.021 & 1.000 & 1.008 & 0.982 & 1.012 & 0.991 \\
\hline 94-95 & 0.994 & 1.008 & 0.955 & 1.001 & 1.010 & 1.012 & 0.980 & 1.024 \\
\hline $95-96$ & 0.992 & 1.018 & 0.969 & 0.993 & 0.990 & 1.028 & 0.990 & 1.021 \\
\hline $96-97$ & 0.984 & 1.021 & 1.016 & 1.001 & 1.006 & 0.973 & 1.000 & 0.985 \\
\hline 98-99 & 0.992 & 1.077 & 0.982 & 1.002 & 1.001 & 0.991 & 1.044 & 1.062 \\
\hline 99-00 & 0.987 & 1.070 & 0.966 & 1.000 & 1.015 & 1.012 & 1.049 & 1.083 \\
\hline $00-01$ & 0.992 & 1.064 & 0.968 & 1.003 & 1.008 & 0.975 & 1.009 & 1.041 \\
\hline $01-02$ & 0.992 & 1.059 & 0.954 & 0.998 & 0.996 & 1.043 & 1.042 & 1.087 \\
\hline $02-03$ & 0.994 & 1.053 & 0.979 & 0.986 & 1.027 & 1.012 & 1.050 & 1.071 \\
\hline $03-04$ & 0.990 & 1.046 & 0.990 & 0.976 & 1.007 & 1.006 & 1.015 & 1.025 \\
\hline $04-05$ & 0.988 & 1.037 & 0.965 & 0.986 & 1.016 & 0.902 & 0.894 & 0.929 \\
\hline $05-06$ & 0.984 & 1.032 & 0.956 & 1.001 & 1.007 & 0.987 & 0.966 & 1.010 \\
\hline 06-07 & 0.991 & 1.028 & 0.998 & 1.021 & 0.993 & 0.989 & 1.020 & 1.022 \\
\hline $07-08$ & 0.965 & 1.027 & 0.955 & 1.024 & 1.008 & 1.001 & 0.979 & 1.024 \\
\hline $08-09$ & 0.985 & 1.024 & 0.987 & 1.001 & 1.005 & 1.002 & 1.004 & 1.018 \\
\hline 92-09 & 0.989 & 1.036 & 0.977 & 1.000 & 1.005 & 0.994 & 1.001 & 1.024 \\
\hline $92-97$ & 0.993 & 1.012 & 0.985 & 1.000 & 1.000 & 0.999 & 0.990 & 1.004 \\
\hline 98-09 & 0.987 & 1.047 & 0.973 & 1.000 & 1.007 & 0.992 & 1.006 & 1.033 \\
\hline
\end{tabular}

Note: The superscript * indicates results obtained with reference to the metafrontier. As in (5) the TFP change rate of the Divisia index is given by the sum of scale effect (SC), technical change (TC), the effects of environmental variables (EX), allocative efficiency (ALLC), cost 
efficiency (EC) and the mark-up effect (MU). TFP2 reports overall TFP without taking into account the environmental factors not accounted for in the Malmquist index. 
Table 6: Metafrontier Malmquist Index

\begin{tabular}{|c|c|c|c|c|}
\hline & $S C^{*}$ & $T C^{*}$ & $E C^{*}$ & TFP* \\
\hline $92-93$ & 0.968 & 1.028 & 0.946 & 0.963 \\
\hline 93-94 & 0.969 & 1.116 & 1.041 & 1.126 \\
\hline $94-95$ & 0.958 & 1.066 & 0.965 & 1.018 \\
\hline $95-96$ & 1.007 & 1.029 & 0.917 & 0.975 \\
\hline 96-97 & 0.949 & 1.022 & 1.012 & 0.996 \\
\hline $97-98$ & 0.983 & 1.067 & 1.036 & 1.109 \\
\hline 98-99 & 0.909 & 1.064 & 0.902 & 0.859 \\
\hline $99-00$ & 0.958 & 1.112 & 1.109 & 1.178 \\
\hline $00-01$ & 0.929 & 1.067 & 0.935 & 0.914 \\
\hline $01-02$ & 1.003 & 1.401 & 1.132 & 1.356 \\
\hline $02-03$ & 0.957 & 1.164 & 1.008 & 1.065 \\
\hline $03-04$ & 0.924 & 1.256 & 0.998 & 1.132 \\
\hline $04-05$ & 0.927 & 1.030 & 0.825 & 0.765 \\
\hline $05-06$ & 0.949 & 1.007 & 0.973 & 0.986 \\
\hline $06-07$ & 0.998 & 1.009 & 0.942 & 1.054 \\
\hline $07-08$ & 1.010 & 1.050 & 0.977 & 1.131 \\
\hline 08-09 & 0.978 & 1.022 & 0.977 & 1.016 \\
\hline $92-09$ & 0.963 & 1.085 & 0.979 & 1.030 \\
\hline 92-97 & 0.970 & 1.052 & 0.975 & 1.014 \\
\hline 98-09 & 0.960 & 1.099 & 0.981 & 1.036 \\
\hline
\end{tabular}


Note: The superscript $*$ indicates results obtained with reference to group the metafrontier. $\mathrm{TFP}=$ total factor productivity $; \mathrm{TC}=$ technical change $; \mathrm{EC}=$ efficiency change $; \mathrm{SC}=$ scale change. 
Table 7: Technological Gap Ratio, Cost Efficiency and Metaefficiency

\begin{tabular}{|c|c|c|c|c|}
\hline DEA & & 1992-1997 & 1998-2009 & 1992-2009 \\
\hline \multirow[t]{4}{*}{$T G R$} & State & 0.862 & 0.740 & 0.781 \\
\hline & Foreign & 0.810 & 0.810 & 0.810 \\
\hline & Private & 0.706 & 0.764 & 0.745 \\
\hline & All & 0.793 & 0.771 & 0.779 \\
\hline \multirow[t]{4}{*}{$\boldsymbol{E F F ^ { k }}$} & State & 0.910 & 0.892 & 0.898 \\
\hline & Foreign & 0.908 & 0.868 & 0.881 \\
\hline & Private & 0.697 & 0.622 & 0.647 \\
\hline & All & 0.827 & 0.777 & 0.794 \\
\hline \multirow[t]{4}{*}{$E F F^{*}$} & State & 0.784 & 0.657 & 0.699 \\
\hline & Foreign & 0.735 & 0.702 & 0.713 \\
\hline & Private & 0.491 & 0.475 & 0.480 \\
\hline & All & 0.670 & 0.611 & 0.631 \\
\hline \multicolumn{5}{|l|}{ SFA } \\
\hline \multirow[t]{4}{*}{$T G R$} & State & 0.949 & 0.826 & 0.867 \\
\hline & Foreign & 0.935 & 0.828 & 0.864 \\
\hline & Private & 0.891 & 0.765 & 0.806 \\
\hline & All & 0.924 & 0.802 & 0.842 \\
\hline \multirow[t]{2}{*}{$E F F^{k}$} & State & 0.923 & 0.922 & 0.922 \\
\hline & Foreign & 0.888 & 0.884 & 0.885 \\
\hline
\end{tabular}




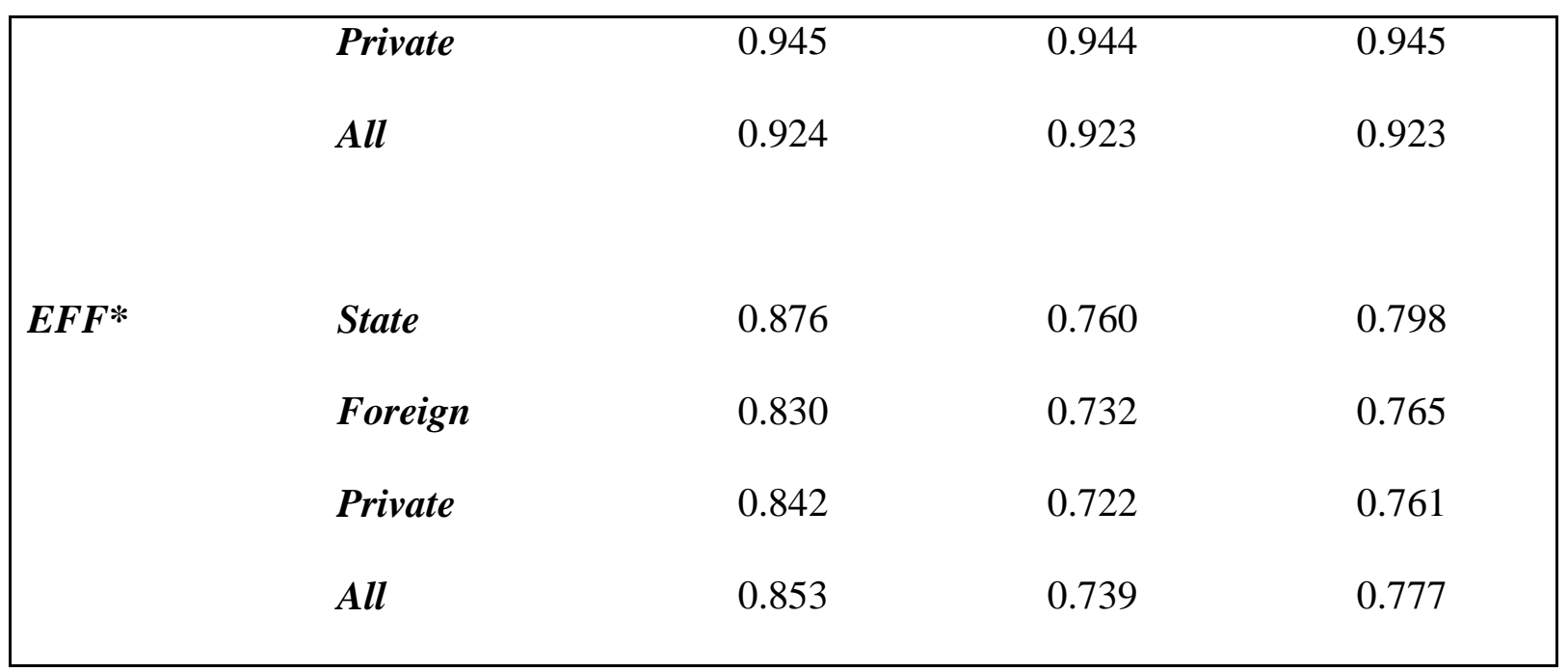

Note: The superscript $\mathrm{k}$ indicates results obtained with reference to group specific frontiers; * indicates results obtained with reference to group specific frontiers. $T G R=$ Technological Gap Ratio; $\mathrm{EFF}^{\mathrm{k}}=$ cost efficiency; $\mathrm{EFF}^{*}=$ metaefficiency. 
Table 8: Number and proportion of technology leaders per ownership category

\begin{tabular}{|lcccccccc|}
\hline & \multicolumn{3}{c}{ SFA } & & \multicolumn{3}{c|}{ DEA } \\
& \multicolumn{1}{c}{ 1992-1997 } & \multicolumn{2}{c}{ 1998-2009 } & 1992-1997 & 1998-2009 \\
& No. & $\%$ & No. & $\%$ & No. & $\%$ & No. & $\%$ \\
Foreign & 11 & 34 & 12 & 48 & 10 & 19 & 40 & 38 \\
Private & 9 & 28 & 7 & 28 & 9 & 17 & 30 & 29 \\
State & 12 & 38 & 6 & 24 & 34 & 64 & 34 & 33 \\
\hline
\end{tabular}


Table 9: catch-up index pre and post 1998 per ownership group.

\begin{tabular}{|rrrrrrr|}
\hline & & SFA & & & DEA & \\
& $\boldsymbol{S}$ & $\boldsymbol{F}$ & $\boldsymbol{P}$ & $\boldsymbol{S}$ & $\boldsymbol{F}$ & $\boldsymbol{P}$ \\
$\mathbf{9 2 - 9 7}$ & 0.990 & 0.976 & 1.007 & 1.019 & 0.928 & 0.905 \\
$\mathbf{9 8 - 0 9}$ & 1.047 & 0.996 & 1.030 & 1.082 & 0.968 & 1.004 \\
\hline
\end{tabular}


Table 10: ADF test of convergence of (12)

\begin{tabular}{|lcccccc|}
\hline DEA & \multicolumn{2}{c}{ Foreign } & \multicolumn{2}{c}{ State } & \multicolumn{2}{c|}{ Private } \\
& Estimate & P-value & Estimate & P-value & Estimate & P-value \\
$\left(\gamma_{\left.\mathrm{k}-\gamma^{*}\right)}\right.$ & 0.013 & 0.410 & -0.044 & 0.327 & 0.000 & 0.985 \\
$\boldsymbol{\lambda}$ & 0.764 & 0.021 & 0.814 & 0.290 & 0.461 & 0.378 \\
SFA & & & & & & \\
$\left(\gamma_{\mathrm{k}}-\gamma^{*}\right)$ & 0.003 & 0.190 & -0.001 & 0.177 & -0.001 & 0.505 \\
$\lambda$ & 0.233 & 0.06 & 0.108 & 0.025 & 0.106 & 0.442 \\
\hline
\end{tabular}

Note: This is an ADF test with one lagged difference term. We report directly the value of $\lambda$ and its p-value is the MacKinnon p-value. 
Figure 1: TGR distribution from SFA pre and post 1998 per ownership group

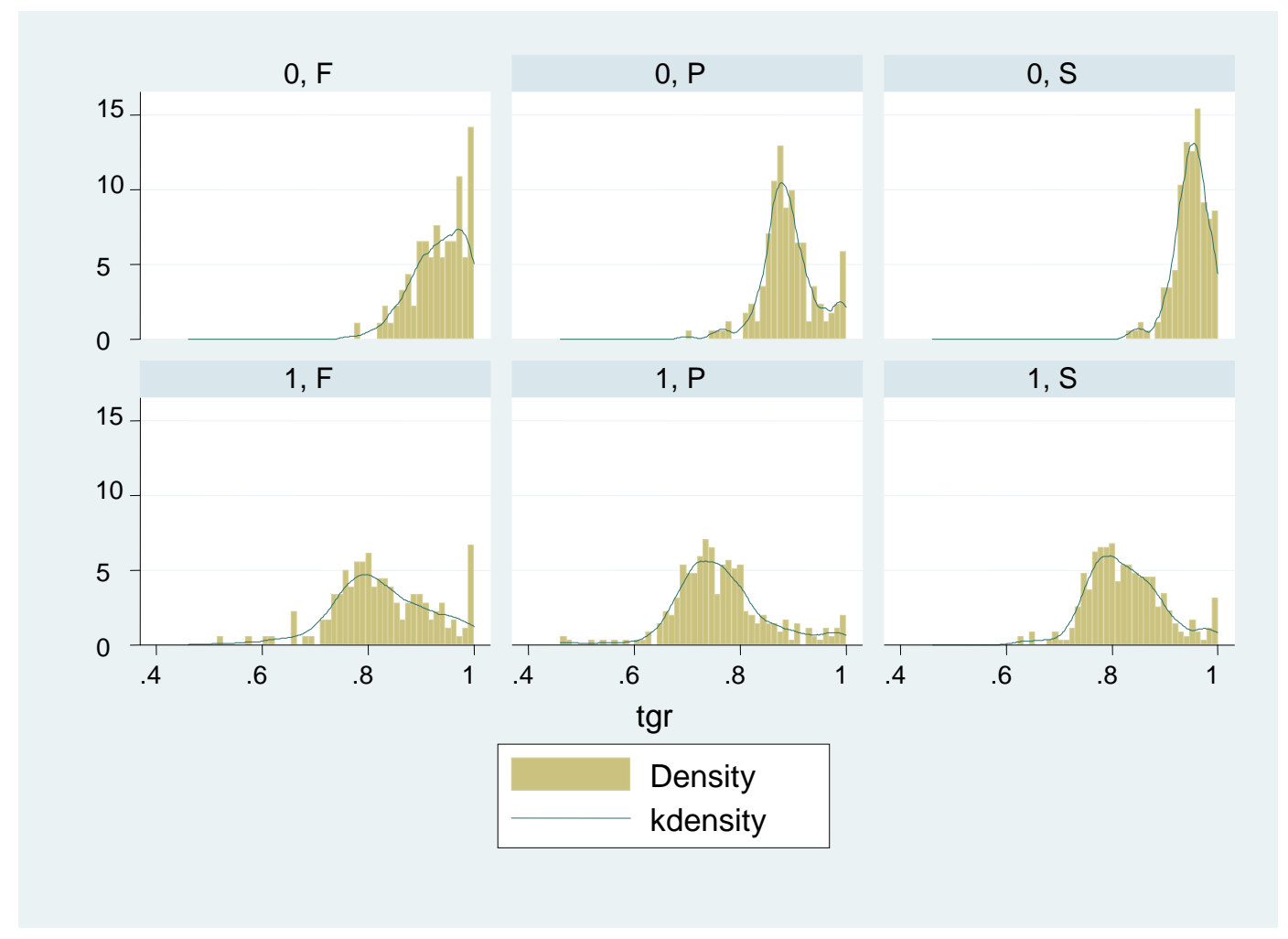


Figure 2: TGR distribution from DEA pre and post 1998 per ownership group

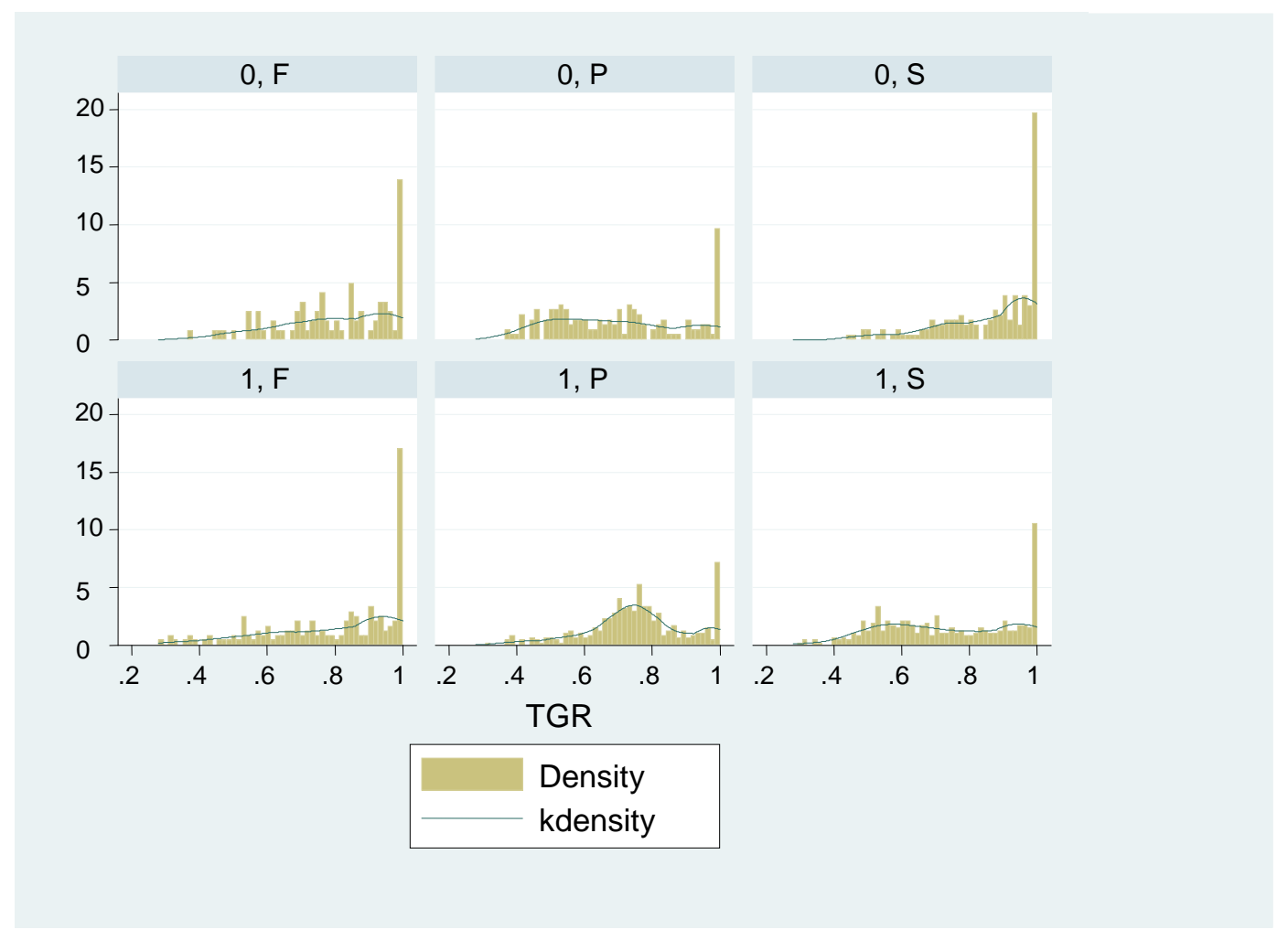




\section{ENDNOTES}

${ }^{1}$ The positive impact of financial reforms on the technology of production is typically based on two arguments. First, the overall cost of producing at a given level of output is reduced by declining compliance costs. Second, regulatory reforms usually reduce restrictions on activities, thereby offering the opportunity for banks to take advantage of economies of scale and scope. Efficiency improvements are expected to arise from the increased competitive pressures that reduce managerial inefficiencies.

${ }^{2}$ For detailed reviews of the impact of financial reforms on the productivity change of banking systems see for example Mukherjee et al, (2001), and Kumbhakar and Sarkar (2003).

${ }^{3}$ Deregulation seems to increase efficiency for all banks but does not result in interownership convergence (Bonaccorsi di Patti and Hardy, 2005); different ownerships react with different speeds to the change of regulatory environment (Isik and Hassan, 2003; Leightner and Lovell, 1998); ownership structure becomes neutral in terms of productivity growth and a diverse ownership structure also functions as a stimulus to market competition (Sturm and Williams, 2004). A detailed literature review on this issue can be found in Sturm and Williams (2004).

${ }^{4}$ Structural deregulation was characterised by the removal of entry restrictions to private ownership, liberalization of interest rates on deposits and lending, and an increase in the range of permitted activities. Prudential norms related to assets classification, income recognition, provisioning, risk-based capital adequacy and informational disclosure.

${ }^{5}$ See Cole (2009) for a discussion of the relevance of bank ownership and economic growth.

${ }^{6}$ For a review of early literature see Berger and Humphrey (1997), and Goddard et al (2001). Reviews of more recent literature are presented, among others, by Berger (2007); Goddard et al (2007), Cook and Seiford (2009); Hughes and Mester (2010). 
${ }^{7}$ Performing loans are measured as the difference between total loans and non-performing loans. Other earning assets aggregate government securities, other approved securities, shares, debentures and bonds, subsidiaries and joint ventures and other investment outside India (i.e. total investment).

${ }^{8}$ According to the accounting practice followed by the Indian banking sector post-1992, income accrual would cease once the loan is recognized as non-performing. Therefore, the interest received on loans recorded in the loss and profit account is associated with the performing loans.

9 For a general review of the methodological approaches to efficiency and productivity measurement see for instance Fried et al. (2008).

${ }^{10}$ The subscripts $c$ and $v$ refer to whether the distance function is with respect to a constant returns to scale frontier or a variable returns to scale frontier.

${ }^{11}$ The estimation of a sequential frontier changes the superscript in Equation (1) from $t$ to all the periods up to time $t$, i.e. $1,2,3, \ldots$. t. The technical details can be found in Tulken and Vanden Eeckaut (1995) and Thirtle et al. (2003).

${ }^{12}$ This is essentially like a problem of degrees of freedom, leading to excessive estimates of efficiency when the number of variables is too high relative to the number of observations.

${ }^{13}$ We did not introduce fixed effects into the model as most of the heterogeneity seemed handled satisfactorily by the chosen variables and the separation of the ownership frontiers, as usefully suggested by an anonymous referee. Indeed as noted by Zhou (2001) a fixed effects estimation uses within-groups variation; since many of the regressors change only gradually over time this can potentially lead to over control and an overshadowing of the cross sectional relationship.

${ }^{14}$ As we will see this choice is based on a test of whether the data can be pooled.

${ }^{15}$ In (9) the hat notation indicates the estimator of the corresponding parameter. 
${ }^{16}$ Given the focus of the paper and for reasons of space we do not provide a detailed discussion of the ownership-specific frontiers. The main results of their estimation are reported in Table A2 in the appendix.

${ }^{17}$ Private banks are the most heterogeneous group in the sample, hence the more "noisy" as they experience the largest number of entries and exits, mergers and acquisitions and show significant differences also depending on whether they are "old" or "new", as confirmed by the stochastic cost frontier results. The presence of all this noise cannot be accounted for by DEA which therefore ranks any of the bad performers much worse than SFA does.

${ }^{18}$ To make the comparison possible we transformed the TFP growth rate of the Divisia index into a TFP growth as the Malmquist.

${ }^{19}$ We also estimated a single metafrontier for the whole time period. The results were unsatisfactory and therefore are not reported.

${ }^{20}$ As discussed in the methodology section, TGR is computed as the ratio of metaefficiency to cost efficiency.

${ }^{21}$ Recall that increases in the technological gap ratios imply decreases in the gap between the group frontier and the metafrontier. The higher the ratio, the closer the group frontier is to the metafrontier (i.e. best available technology) and vice versa.

${ }^{22}$ The notable difference in the absolute number of technology leaders between the two methodologies is explained by their deterministic $v s$ stochastic nature. Indeed if we were to lower the threshold even just to $99 \%$ for SFA the results would be remarkably closer. 